\title{
The perspective of ergonomics in the design of work situations using computational tools: case in a plastic film manufacturing plant
}

\author{
Andréa Regina Martins Fontes ${ }^{a}$, Daniel Braatz ${ }^{b}$ João Eduardo Azevedo Ramos da Silva ${ }^{a}$, Rosane Ferreirab \\ Nilton Luiz Menegon ${ }^{b}$ \\ ¿Departamento de Engenharia de Produç̃̃o Campus Sorocaba - DEPS, Universidade Federal de São Carlos - UFSCar \\ bDepartamento de Engenharia de Producão - DEP, Universidade Federal de São Carlos - UFSCar \\ e-mails: andreaf@dep.ufscar.br; braatz@ufscar.br; jesilva@ufscar.br; rosanealvesferreira@gmail.com; menegon@dep.ufscar.br
}

\begin{abstract}
Simulation supports are intermediary objects that help in anticipating the behavior of production systems are important in designs that involve Ergonomics Work Analysis (EWA) method and Future Activity Analysis (FAA) approach. The objective is to describe the process of transformation design of a productive situation using three areas of study: Ergonomics, Simulation and Plant Layout Design. The focus is on the application of intermediary objects during the design process. This article involves a reflective practice of a single case study in which the activity-centered ergonomics approach was employed in the design of productive situations. The described case took place at a plastic film roll manufacturing plant. In this work were used the computational techniques and tools for the design of productive situations: Computer Aided Design, Digital Human Modeling and Simulation, Discrete Event Simulation and Game Engine. The use of these intermediary objects potentially reduces the time spent on design, makes better use of investment resources, contributes to an understanding of current and future capacity, and provides ergonomic improvements of the work situation for future users. The integration of different intermediate objects at the perspective of ergonomics, like digital human simulation, discrete event simulation and game engine can contribute to simulate future work in the design process.
\end{abstract}

Keywords: ergonomics, workspace design, simulation, intermediary objects.

\section{Introduction}

This paper discusses the design of work situations in participatory ergonomics. In this context, this research highlights the standpoint of activity as an engineering design paradigm, focusing on the use of intermediary objects as anticipators of future work and a means of communication in the participatory design process (JONG; VINK, 2002; BROBERG; ANDERSEN; SEIM, 2011; VINCK, 2011; ANDERSEN; BROBERG, 2015; BITTENCOURT; DUARTE; BÉGUIN, 2017).

Based on the Activity-centered Ergonomics approach, in which the concept of work centers on activity (GARRIGOU et al., 1995; WISNER, 1995; GUÉRIN et al., 2001), two key points for the development of this research are highlighted: the (re)construction of activity (DANIELLOU; RABARDEL, 2005; BÉGUIN, 2008a) and the intermediary objects of design (VINCK, 2011; ANDERSEN; BROBERG, 2015; BÉGUIN, 2008b; BROBERG, 2008; VINK; RHIJN; SEIM, 2008; SEIM, BROBERG, 2010).
Interventions in productive situations seek to meet different objectives according to the historical moment, region and economy in which they operate. In the logic of Ergonomics, the transformation of a work situation necessarily includes the means of performing the likely future work (DANIELLOU, 2002). This relationship is inseparable - one cannot think of environments and technical work devices as separate from their use in fulfilling the task. In other words, the perspective of the activity must be integrated in the design right from the start, when the choices occur at the work system level, rather than at the end, when the discussion covers specific issues related to work stations (JONG; VINK, 2002; BÉGUIN, 2007; LIMA; DUARTE, 2014).

The method of activity-centered ergonomics is Ergonomic Work Analysis (EWA). The main characteristic of EWA is that it is a method for examining the complexity of work, responding to a specific question and guiding proposals for operative solutions (WISNER, 2004). In this study, the issue to be addressed is the packaging task in a 
plastic film manufacturing plant, which is analyzed and reconstructed from the ergonomic standpoint.

Simulation supports that help in anticipating the behavior of production systems are important in designs that involve EWA and Future Activity Analysis (FAA) (BÉGUIN, 2003; DANIELLOU, 2007). When conducting design processes, digital human modeling and simulation (DHMS) are particularly helpful in building future scenarios and foreseeing situations of use (LARING et al., 1996; COLOMBO; CUGINI, 2005; FRITZSCHE et al., 2012; FONTES et al., 2014). Moreover, in a computing environment, discrete event simulation (DES) is able to reproduce systems under study by means of a model, which is then used to perform experiments, anticipating the analysis of scenarios (KELTON; SADOWSKI; STURROCK, 2007).

The development of the model is one of the phases in simulation design, whose conception implies the observation of the real situation for subsequent modeling, with emphasis on adherence to real production systems (BANKS et al., 2010). The technique focuses on the development of the simulation model, a computational intermediary object, which serves to represent the system of interest at the appropriate represents systems of interest at an appropriate level of detail (BANKS, 1998; KELTON; SADOWSKI; STURROCK, 2007).

Based on a case study, the purpose of this paper is to describe the process of transformation design of a productive situation using three areas of study, Ergonomics, Simulation and Plant Layout Design, focusing on the application of intermediary objects as interfaces.

This article is structured as follows: This section, the introduction, presents the objective, theoretical background and structure of the text; section two explains the method employed; section three describes the results; section four discusses these results; and section five presents our conclusions.

\section{Methods}

The methodology used in this article involves a reflective practice of a single case study in which the activity-centered ergonomics approach was employed in the design of productive situations. The case was developed from a partnership between a plastic film roll manufacturing plant and a research group of the Department of Production Engineering at the Federal University of São Carlos. The choice of case study as a research method occurred because it was used to explore and examine relationships between data in depth from different sources of evidence (YIN, 2009). This author also concluded that multiple sources increase the credibility, reliability and confirmation of the study.

The research presents intermediary objects as interfaces between the fields of study, which were used in the case to reconstruct the activity from an existing situation. Figure 1 illustrates the conceptual and methodological framework used in the project.

Intermediary objects enable the establishment of links to be established between the three fields of study and their relationship, in order to understand the initial context and to design the new reality of the future workstation.

Work Analysis and Design were carried out in the field of Ergonomics; Physical Design Alternatives and Production Factors were evaluated by means of Simulation; and the Physical Layout Design was developed by Plant Design. This sequence of activities of the project was nonlinear, i.e., some of the stages were carried out concomitantly. Table 1 describes the areas of development of this study, the stages, methods, techniques and tools of process analysis and design.

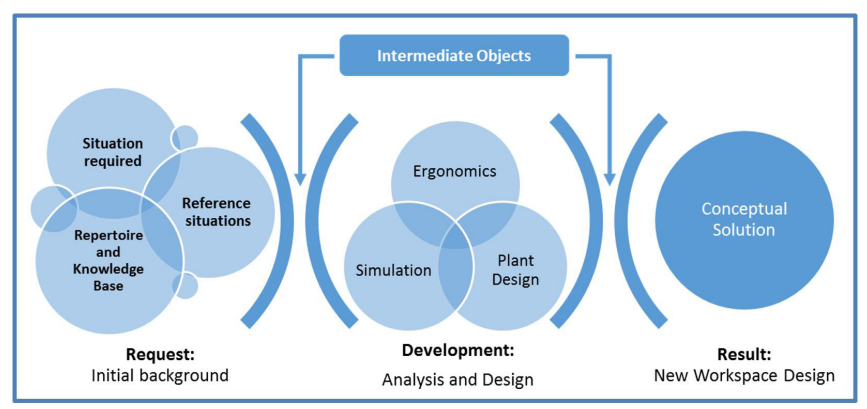

Figure 1. Conceptual framework for activity-oriented approach to ergonomics and plant design.

Table 1. Areas of study of the design process.

\begin{tabular}{|c|c|c|}
\hline $\begin{array}{l}\text { Areas of } \\
\text { study }\end{array}$ & Stages & Techniques and Tools \\
\hline \multirow{6}{*}{ Ergonomics } & Demand analysis & \multirow{4}{*}{$\begin{array}{l}\text { Films, Task Description } \\
\text { Sheet; Ergonomic Work } \\
\text { Analysis (EWA) and } \\
\text { Perception Questionnaire }\end{array}$} \\
\hline & Task analysis & \\
\hline & Activity analysis & \\
\hline & Diagnosis & \\
\hline & $\begin{array}{l}\text { Participatory Conceptual } \\
\text { Design }\end{array}$ & \begin{tabular}{|l|}
$\begin{array}{l}\text { AutoCAD } 2013 \\
\text { (Autodesk) }\end{array}$ \\
\end{tabular} \\
\hline & $\begin{array}{l}\text { Human Simulation } \\
\text { (Static and Dynamic) }\end{array}$ & $\begin{array}{l}\text { Delmia }^{\circledR} \text { V5R18 - } \\
\text { Human Builder }{ }^{\circledR} \text { Module } \\
\text { (Dessault Systèmes) }\end{array}$ \\
\hline \multirow{3}{*}{$\begin{array}{l}\text { Discrete } \\
\text { event } \\
\text { simulation } \\
\text { (DES) }\end{array}$} & $\begin{array}{l}\text { Conceptualization and } \\
\text { infrastructure }\end{array}$ & \multirow{3}{*}{$\begin{array}{l}\text { Computational modeling } \\
\text { with Arena }^{\circledR} \text { v. } 11.0 \\
\text { (Rockwell Software) }\end{array}$} \\
\hline & Modelling & \\
\hline & Simulation & \\
\hline \multirow{8}{*}{$\begin{array}{l}\text { Plant } \\
\text { Design }\end{array}$} & Equipment list & \multirow{8}{*}{$\begin{array}{l}\text { AutoCAD }{ }^{\circledR} 2013 \\
\text { (Autodesk), Photos, } \\
\text { films, on-site } \\
\text { measurements, Game } \\
\text { Engine }\end{array}$} \\
\hline & Product mix & \\
\hline & Production flows & \\
\hline & Templates & \\
\hline & 2D Layout & \\
\hline & 3D Modeling & \\
\hline & 3D Layout & \\
\hline & Virtual scenarios & \\
\hline
\end{tabular}




\section{Results}

\subsection{Case development}

The case described in this paper took place at a plastic film roll manufacturing plant. The production process consists of operations that can be grouped into film roll production, roll cutting, and roll packaging. Some of the rolls are metalized before packaging or cutting into smaller rolls.

The project developed at the manufacturing plant consisted of ergonomic work analysis in the film metallization, roll cutting and packaging departments; as well as a general study of layout and materials handling. This case was selected for analysis as the final solution for the operations could provide the ergonomic analysis to overall layout design and materials handling in a bottom-up approach.

The project was carried out by working group composed of members of the university (four teachers, two masters students and eight undergraduates of the areas of production engineering, ergonomics, simulation and health) and by members of the company (production managers/supervisors, engineering, and occupational safety/health).

This article discusses the packaging task and the results are grouped in three sections presented below.

\subsubsection{Ergonomics}

The ergonomic study used EWA (GARRIGOU et al., 1995; WISNER, 1995) in the stages of demand, task and activity analysis in order to assess the determinants of work situation constraints. Based on these analyses, a diagnosis was prepared to support a discussion about the difference between task and activity, variability, workload and mode of operation.

Based on the diagnosis, a conceptual design was created of the future situation, which was the result of a collective construction aided by a human modeling and simulation software program. The purpose of this intermediary object was to render the solution proposals explicit in order to instigate discussions and developments within the working group.

The EWA and the development activities of the conceptual design involved the following procedures: systematic filming of the work situations, drafting of task description sheets detailing the difficulties involved in each operation performed at the analyzed workstations, application of the EWA tool to assess the risks to which workers are exposed in each situation, application of perception questionnaires to workers of the workstations (79 respondents), physical modeling using Computer Aided Design (CAD), and human simulation in digital environments to anticipate uses at the workstations.

The images in Figure 2 represent work situations modeled in AutoCAD ${ }^{\circledR}$ and exported to the DHMS Human Builder tool - Delmia ${ }^{\circledR}$ (Dassault Systèmes) of a pallet cart (packaging task). These intermediary objects enabled the working group to evaluate different design parameters in different anthropometric extremes, selecting requisites for the technical device. The application of this support is also discussed by (FONTES et al., 2014).

Figure 3 shows a sequence of images taken from a film of the dynamic simulation. This type of animation enabled
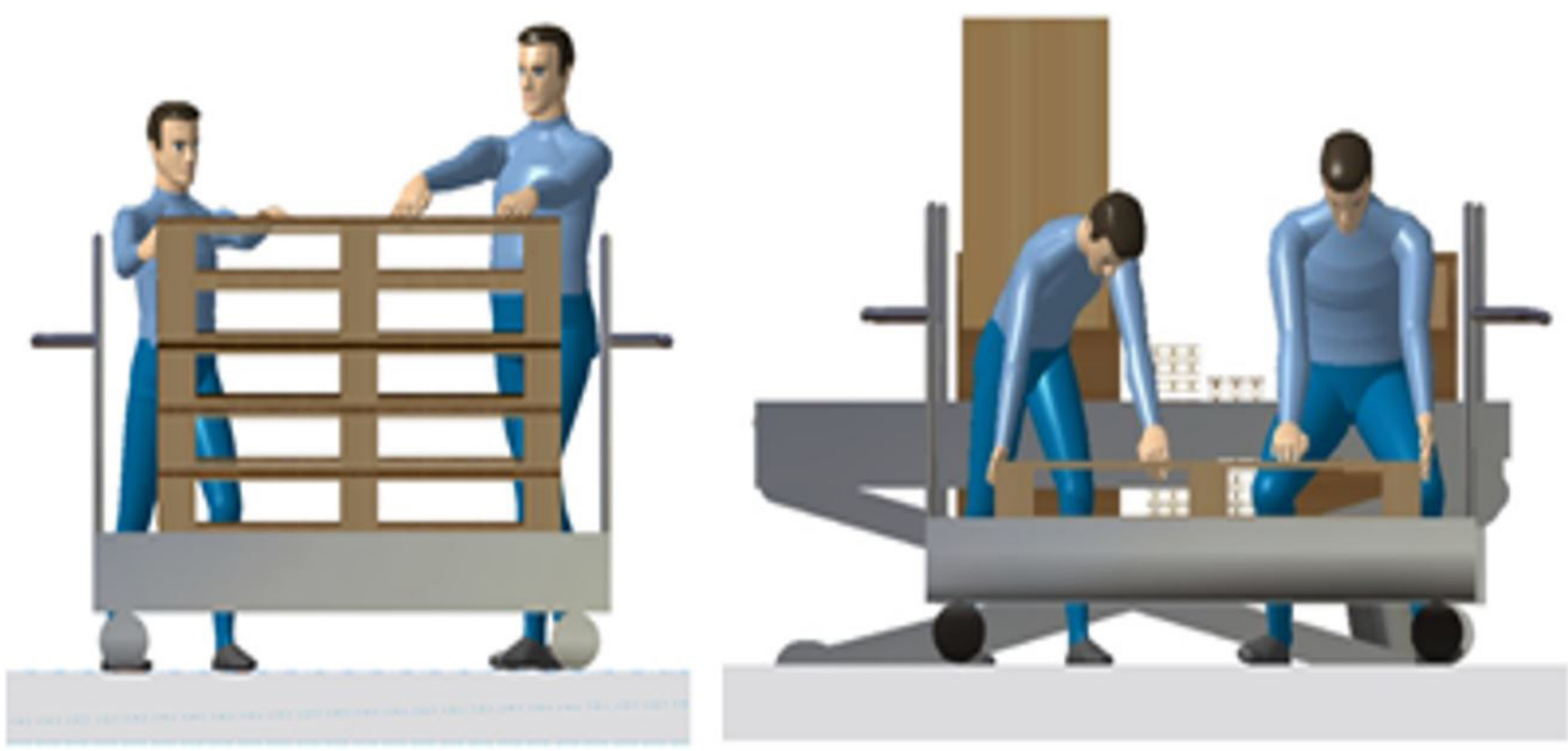

Figure 2. Static simulation with tests of anthropometric extremes. 


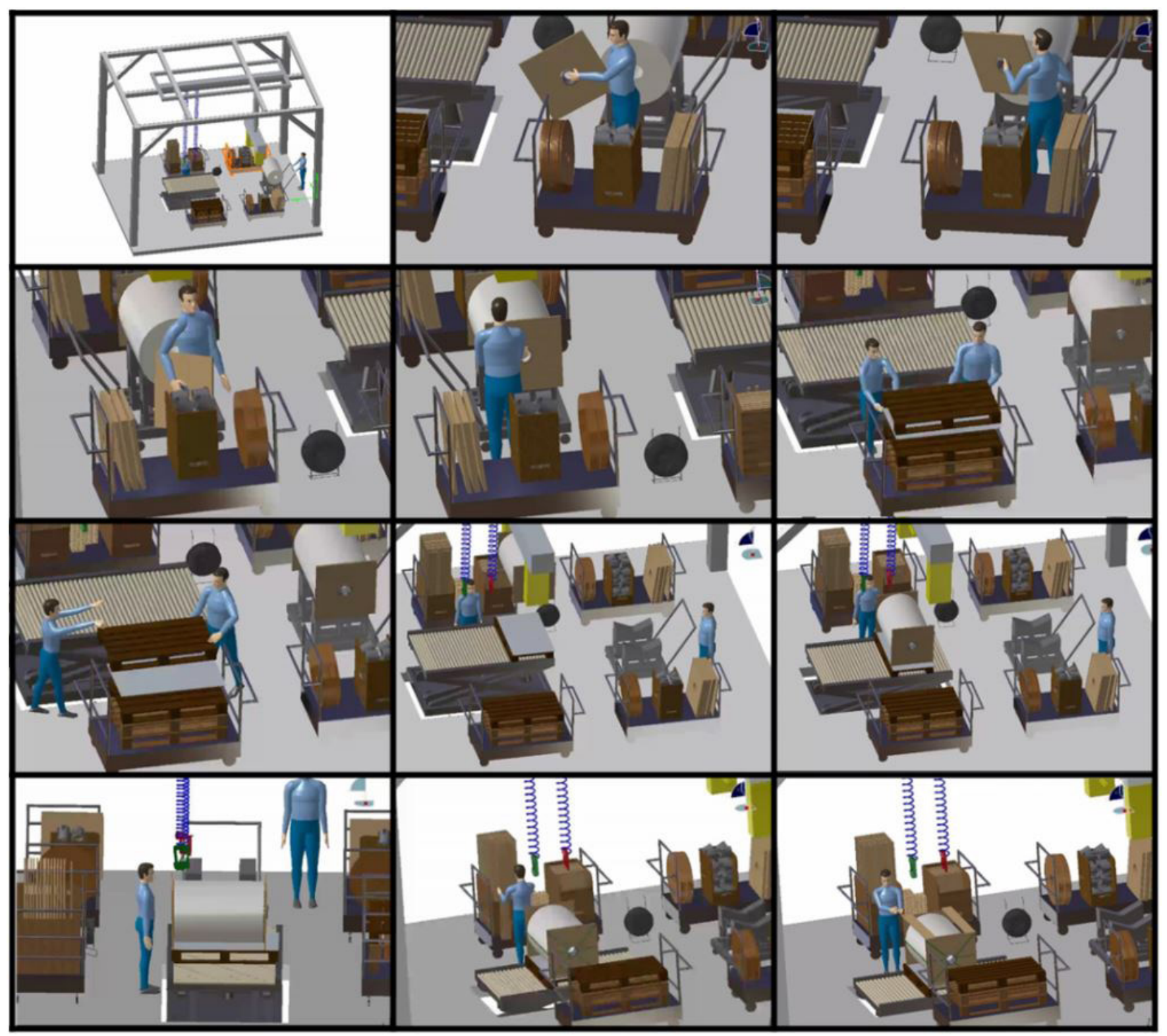

Figure 3. "Human dynamic simulation - packaging department" intermediary object created with DHMS.

the working group to visualize the likely future activity in different work scenarios.

Dynamic simulation tool enables the understanding of the sequence of activities at plastic packing workstation.

\subsubsection{Discrete event simulation}

The purpose of the simulation study, which was carried out using discrete-event simulation software, was to develop a model of the company's operations and simulate alternatives designed for reference scenario, for validation, and future scenario, according to the new layout design.

The operations represented were primary and secondary roll cutting, metallization process and packaging for inventory or shipping, besides the rolls handling required by these areas.

Several authors (KELTON; SADOWSKI; STURROCK, 2007; BANKS et al., 2010; BANKS, 1998) present similar methodologies for DES projects, divided into stages. Based on these authors, the simulation study consisted of three stages: conceptualization and infrastructure; modeling; and simulation.

In the initial stage, conceptualization and infrastructure, the operations to be designed were defined, concurrently with the physical layout design, using the company's data on production times and equipment maintenance based on available records. 
The next step, modeling, involved the creation of the simulation model for the two outlined scenarios, which were validated jointly by the company and research group teams, based on the company's production figures.

Lastly, in the actual simulation stage, the model was run for a one-year production horizon. A set of performance indicators was considered, which included the production of rolls by type, percentage of utilization of production resources (cutting and metallization machines, and packaging team), percentage of utilization of material handling equipment (forklifts), and roll storage area (quantification of pallet positions). Figure 4 shows a software representation of the discrete simulation of the area of the packaging process. The graphic interface was used both as a means to verify if the model represented the operations properly and to validate the model's responses to reality.

As previously discussed, ergonomic problems were reported at packaging activities at floor level, due to inappropriate positioning of workers at plastic film roll fixing on pallets. With the agreement of stakeholders from the company and university's teams, a new alternative was designed by means of an elevator platform and a cart for better location of packaging accessories. Ergonomic techniques and tools (listed at Table 1) supported the new project. However, as new procedures and operation time were consequently modified, the simulation model was used to evaluate the new productivity of packaging department, under a more appropriate ergonomic condition.

\subsubsection{Facility layout and design}

The study of the layout and movement of materials in the areas of primary and secondary cutting, metallization, and cutting of metallized rolls, was accomplished by means of CAD modeling aided by photos, filming and on-site measurements. The purpose of this study was to rearrange the equipment in the sectors of the plant, evaluating different layout possibilities and their impacts.

This study was followed by the construction of the virtual scenario for validation using Game Engine (GE), a computer program with libraries that simplify the development of electronic games. The creation of these $3 \mathrm{D}$ models resulted in a figurative representation of the situation, allowing considerations about ergonomic aspects, safety and interference between activities and sectors to be introduced in the design process.

The final proposal for transforming the work situations was validated with intermediary object "virtual scenario", which was created with the support of a Game Engine. Figures 5 and 6 illustrate this scenario.

Virtual scenario, as seen in Figures 5 and 6, provides a better understanding of the proposals of future layout, manly production resources equipment positioning, space occupation and their mutual interaction.

\section{Discussion}

Ergonomics is one of the ways used in engineering to successfully incorporate the possible future activities of workers/users of technical systems in designs (or re-designs)

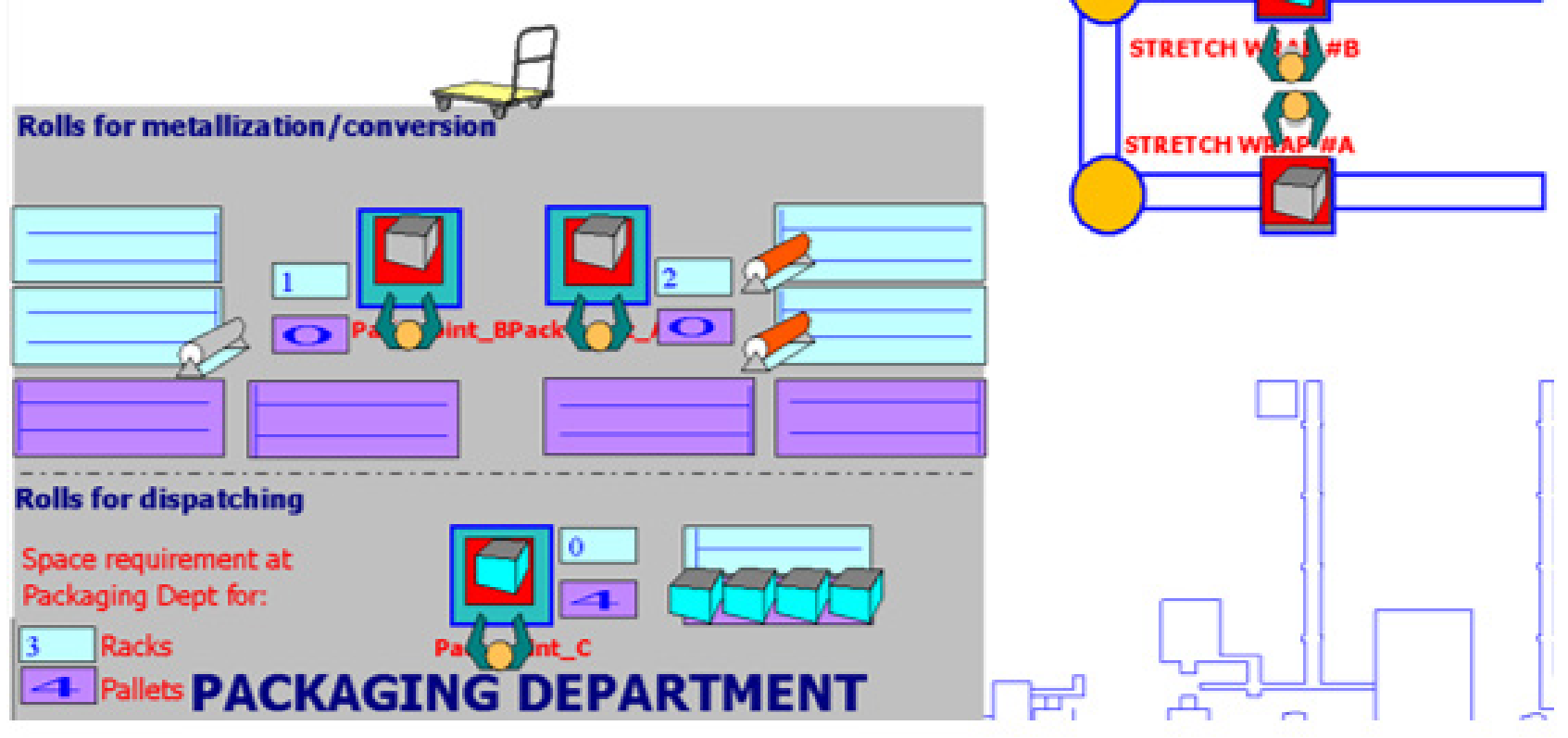

Figure 4. "Simulation model - packaging department" intermediary object created with DES. 


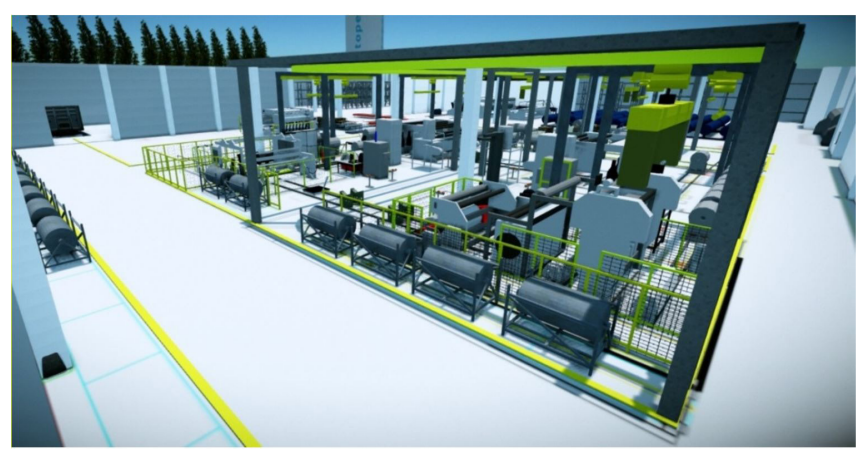

Figure 5. "Virtual scenario - roll cutting sector" intermediary object created with Game Engine.

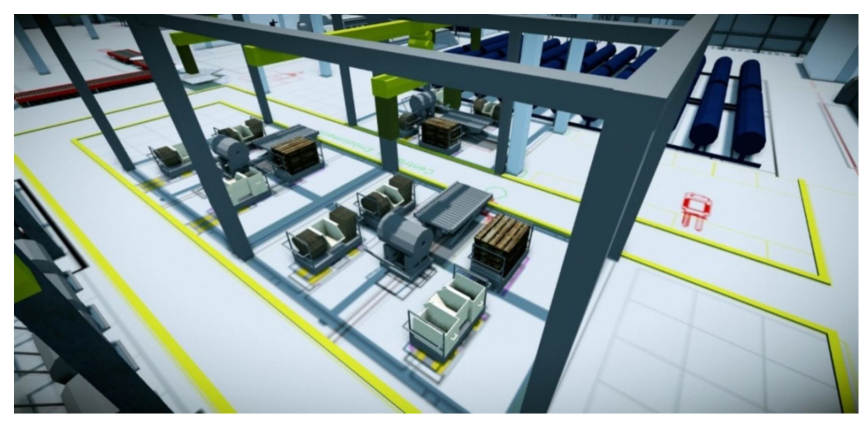

Figure 6. "Virtual scenario - packaging department" intermediary object created with Game Engine.

(BÉGUIN, 2003). Project teams should therefore use participatory approaches with different intermediary objects, such as the computational objects discussed in this article. The use of intermediary objects allows one to schematize and qualify the relationships between actors (creating bridges between different technical and social worlds), and provides support for project development, recording and documenting the temporal evolution of the phases (VINCK, 2009).

There are several computational techniques and tools for the analysis and conception of production systems (ZÜLCH, 2012). In this work, four main types of software programs were used for the design of productive situations: CAD, DES, GE and DHMS.

CAD tools are used to create floor plans and physical layouts. The general characteristics of designs or projects created with this technology have high dimensional accuracy, the possibility of incorporating large amounts of technical information about the object and the environment in which it is inserted, and the possibility of creating new and different versions without the need to lose information. Another key feature of projects developed in CAD is the static nature of its representation, but this can be changed by using other technologies such as, for instance, simulation tools, which add a dynamicity that is closer to the real world and facilitate visualization/interaction with the model.

The use of computing environments allowed the development of various types of simulation. Digital human modeling and simulation (DHMS) tools are used because of the need to incorporate the human element in the design, enabling the analysis of biomechanical and postural requirements of future tasks, the validation of areas and their scope of action, and the prediction of visual ranges and accessibility. Moreover, simulation allows the assessment of virtual environments through the analysis of new work situations in different scenarios, and hence is more than simply a means of representing reality (BRAATZ et al., 2013).

The instrumented use of this object enabled us to include in the discussion not only the physical issues but also work organization-related issues, by allowing, for example, an analysis of the collective work in the proposed scenario. This understanding was facilitated and supported by the dynamic and static simulations.

Another characteristic of discrete event simulation that must be evidenced is the possibility to better represent real life proceedings. Theoretical probability distributions are used in the models, based on historical data collected in real work situations, which brings a more realistic representation.

As for the usefulness of discrete event simulation, its relevance increases as production systems become more dynamic and present a higher interaction between the resources involved. This interaction is not limited only by human-machine interface, but also includes rules that condition work (working shifts, stoppages, meals scheduling, etc.), operational rules (setup, sequencing, etc.) and materials availability and finished product flows. Thus, as an intermediary object of the design process, the simulation model successfully represented these elements.

From the quantitative standpoint, it was possible to quantify the materials handling equipment to the new layout, and validate the roll cutting, metallization and packaging resources, and to determine the required size of the product storage area. To complement the quantitative results, the model made specific contributions to the design process. The main contribution was the achievement of a communication channel and the possibility of interaction among the members of the work team.

Although the graphic representation has a lack of details due to $2 \mathrm{D}$ representation, the model was useful for detecting modeling inconsistencies (e.g., by means of queues behavior analysis, identification of the status of resources and the occupation of storage positions) and dynamically monitoring the system's evolution over time. Displays and other graphic elements were used to indicate, for instance, queue sizes, the status of production resources 
and the production of rolls. It was also possible to monitor the operation of materials handling resources (forklifts and carts). The queue dynamics enabled the identification of space required for the rolls on the shop floor, and the need for pallet storage positions.

The application of Game Engine for purposes other than entertainment has been investigated in several areas, including architecture, safety, medicine and tourism. The discussion of the facility layout and design was facilitated by the high graphic quality of representation of the 3D environment, extensive library, easy interaction, and the possibility of event programming. However, the platform presented limitations in terms of available modeling, in updating designs imported from CAD files, and in terms of the accuracy of measurements.

It must be evidenced that these tools facilitated the understanding of design project proposals of the working group members (designers and non-designers), enabling them to participate more actively in the discussion and conception of workspaces and in the design and dimensioning of the production factors. The inclusion of the human element in the graphic representations allowed a better reflection about future work, which supported in the technical and social construction of the solution.

\section{Conclusions}

Based on the results obtained in this case, it can be concluded that the use of these intermediary objects potentially reduces the time spent on design, makes better use of investment resources, contributes to an understanding of current and future capacity, and provides ergonomic improvements of the work situation for future users.

In addition, such simulations enable one to predict both production and worker needs, playing a key role in favoring and encouraging the participation of the various stakeholders in the construction and validation of future work scenarios.

Lastly, it was concluded that a need for innovation in the design of productive units is the inclusion of the perspective of activity (according to the concept of ergonomics), starting from a knowledge base, analysis of reference situations, reconstruction of the activity, and interaction among workers, ergonomists, designers and others involved in the design process. Thus, the application of the tools analyzed here helps both in the technical construction of the proposed solutions and in the social construction involving the various participants.

Considering the limitation that the project was applied to the necessities of one specific company, the integration of intermediate objects at ergonomics, discrete event simulation and plant design areas, can contribute to future research at industrial projects with spatial restrictions and ergonomic requirements. The proposal was afterwards implemented by the focused company, which reveals the strength of the integration of design tools that are commonly used individually.

\section{References}

ANDERSEN, S. N.; BROBERG, O. Participatory ergonomics simulation of hospital work systems: The influence of simulation media on simulation outcome. Applied Ergonomics, v. 51, p. 331-342, 2015. http://dx.doi. org/10.1016/j.apergo.2015.06.003. PMid:26154230.

BANKS, J. Handbook of simulation. 1st ed. New York: John Wiley \& Sons, 1998. 849 p. http://dx.doi. org/10.1002/9780470172445.

BANKS, J. et al. Discrete-event system simulation. 5th ed. Upper Saddle River: Prentice Hall, 2010. 622 p.

BÉGUIN, P. Design as a mutual learning process between users and designers. Interacting with Computers, v. 15, n. 5, p. 709-730, 2003. http://dx.doi.org/10.1016/S09535438(03)00060-2.

BÉGUIN, P. Taking activity into account during the design process. Activités, v. 4, n. 2, p. 115-121, 2007. http://dx.doi. org/10.4000/activites.1727.

BÉGUIN, P. Argumentos para uma abordagem dialógica da inovação. Laboreal, v. 4, n. 2, p. 72-82, 2008a. Available from: $<$ http://laboreal.up.pt/revista/artigo.php?id $=37 \mathrm{t} 45 \mathrm{n}$ SU547112341787:352:81>. Access in: 20 Apr 2018.

BÉGUIN, P. Workers-designers interactions: a developmental approach for an innovative design. In: SNELWAR, L. I.; MASCIA, F. L.; MONTEDO, U. B. (Ed.). Organizational design and management IX. 1st ed. São Paulo: Edgard Blücher, 2008b. p. 585-590.

BITTENCOURT, J. M.; DUARTE, F.; BÉGUIN, P. From the past to the future: Integrating work experience into the design process. Work, v. 57, n. 3, p. 379-387, 2017. http:// dx.doi.org/10.3233/WOR-172567. PMid:28621698.

BRAATZ, D. et al. Digital human modeling and simulation for ergonomics workspace design: two Brazilian cases. In: INTERNATIONAL DIGITAL HUMAN MODELING SYMPOSIUM, 2., 2013, Ann Harbor, Michigan. Proceedings... Michigan: UMTRI, 2013. Available from: $<$ https://www.researchgate.net/publication/262674117_ Digital_Human_Modeling and_Simulation_for Ergonomics_Workspace_Design_two_Brazilian_cases>. Access in: 20 Apr 2018.

BROBERG, O. Quando o projeto participativo de espaços de trabalho se encontra com o projeto de engenharia em eventos de colaboração mútua. Laboreal, v. 4, n. 2, p. 4758, 2008. Available from: <http://laboreal.up.pt/pt/articles/ quando-o-projeto-participativo-de-espacos-de-trabalhose-encontra-com-o-projeto-de-engenharia-em-eventos-decolaboracao-mutua/>. Access in: 20 Apr 2018. 
BROBERG, O.; ANDERSEN, V.; SEIM, R. Participatory ergonomics in design processes: the role of boundary objects. Applied Ergonomics, v. 42, n. 3, p. 464-472, 2011. http://dx.doi.org/10.1016/j.apergo.2010.09.006. PMid:20947061.

COLOMBO, G.; CUGINI, U. Virtual humans and prototypes to evaluate ergonomics and safety. Journal of Engineering Design, v. 16, n. 2, p. 195-203, 2005. http://dx.doi. org/10.1080/09544820500031542.

DANIELLOU, F. A análise da atividade futura e concepção de instalações externas. In: DUARTE, F. (Ed.). Ergonomia e projeto: na indústria de processo contínuo. 1. ed. Rio de Janeiro: Lucerna, 2002, p. 75-83.

DANIELLOU, F. Simulating future work activity is not only a way of improving workstation design. Activités, v. 4, n. 2, p. 84-90, 2007. http://dx.doi.org/10.4000/activites. 1704.

DANIELLOU, F.; RABARDEL, P. Activity-oriented approaches to ergonomics: Some traditions and communities. Theoretical Issues in Ergonomics Science, v. 6, n. 5, p. 353357, 2005. http://dx.doi.org/10.1080/14639220500078351.

FONTES, A. R. M. et al. Complementarities of digital human models and ergonomic work analysis in workstation design: the manual packaging task. International Journal of Human Factors Modelling and Simulation, v. 4, n. 3-4, p. 266-277, 2014. http://dx.doi.org/10.1504/ IJHFMS.2014.067185.

FRITZSCHE, L. et al. Interactive production planning and ergonomic assessment with digital human models: introducing the Editor for Manual Work Activities (EMA). Work, v. 41, p. 4428-4432, 2012. PMid:22317401.

GARRIGOU, A. et al. Activity anaysis in participatory design and analysis of participatory design activity. International Journal of Industrial Ergonomics, v. 15, n. 5, p. 311-327, 1995. http://dx.doi.org/10.1016/0169-8141(94)00079-I.

GUÉRIN, F. et al. Compreender o trabalho para transformálo: a prática da Ergonomia. 1. ed. São Paulo: Edgard Blücher, 2001. 200 p.

JONG, A. M.; VINK, P. Participatory ergonomics applied in installation work. Applied Ergonomics, v. 33, n. 5, p. 439-448, 2002. http://dx.doi.org/10.1016/S00036870(02)00033-9. PMid:12236653.
KELTON, W. D.; SADOWSKI, R. P.; STURROCK, D. T. Simulation with Arena. 4th ed. Boston: McGraw-Hill Higher Education, 2007. 630 p.

LARING, J. et al. Computer aided workplace design: an approach to create a tool for the production engineer. International Journal of Industrial Ergonomics, v. 17, n. 4, p. 323-330, 1996. http://dx.doi.org/10.1016/01698141(95)00063-1.

LIMA, F.; DUARTE, F. Integrating ergonomics to the engineering design: Ergonomic specifications and usage settings. Gestão \& Produção, São Carlos, v. 21, n. 4, p. 679-690, 2014. http://dx.doi.org/10.1590/0104530X733-13.

SEIM, R.; BROBERG, O. Participatory workspace design: a new approach for ergonomists? International Journal of Industrial Ergonomics, v. 40, n. 1, p. 25-33, 2010. http:// dx.doi.org/10.1016/j.ergon.2009.08.013.

VINCK, D. De l'objet intermédiaire à l'objet-frontière Vers la prise en compte du travail d'équipement. Revue d'Anthropologie des Connaissances, v. 3, n. 1, p. 51-72, 2009. http://dx.doi.org/10.3917/rac.006.0051.

VINCK, D. Taking intermediary objects and equipping work into account in the study of engineering practices. Engineering Studies, v. 3, n. 1, p. 25-44, 2011. http://dx.doi. org/10.1080/19378629.2010.547989.

VINK, P.; RHIJN, G.; SEIM, R. Stakeholder involvement in stages of a participatory process illustrated in interior design cases. In: SNELWAR, L. I.; MASCIA, F. L.; MONTEDO, U. B. (Ed.). Organizational design and management IX. 1st ed. São Paulo: Edgard Blücher, 2008. p. 13-18.

WISNER, A. Questões epistemológicas em ergonomia e em análise do trabalho. In: DANIELLOU, F. (Ed.). A ergonomia em busca de seus princípios: debates epistemológicos. São Paulo: Edgard Blücher, 2004. p. 30-53.

WISNER, A. Understanding problem building: ergonomic work analysis. Ergonomics, v. 38, n. 3, p. 595-605, 1995. http://dx.doi.org/10.1080/00140139508925133.

YIN, R. K. Case study research and applications: design and methods. 4th ed. Thousand Oaks: Sage, 2009.

ZÜLCH, G. Features and limitations of digital human models: a new German guideline. Work, v. 41, p. 2253-2259, 2012. PMid:22317050. 